\title{
PENEGAKAN HUKUM PEMERINTAHAN: KEKUASAAN WALIKOTA PEKANBARU MEMBERLAKUKAN BELEIDSREGELS GUNA MEMUTUS PENYEBARAN VIRUS COVID- 19 DI KOTA PEKANBARU
}

\author{
Adlin, ${ }^{1}$ Ali Yusri ${ }^{2}$ \\ Universitas Riau \\ adlin@lecturer.unri.ac.id \\ ali.yusri@lecturer.unri.ac.id
}

\begin{abstract}
Abstrak
Wabah virus Covid-19 pada awal bulan maret 2020 tersebar ke di Indonesia, termasuk di Pekanbaru. Pada tanggal 18 maret 2020, 1 orang pasien positif terinfeksi Covid 19, terdeteksi di Pekanbaru. Kemudian jumlah masyarakat yang diduga terinfeksi semakin meningkat, sehingga tanggal 22 maret 2020 Walikota Pekanbaru, Firdaus merespon dalam konteks pemerintahan dengan menaikkan status tanggap darurat Covid-19 untuk Kota Pekanbaru. Selanjutnya tanggal 23 Maret 2020 Walikota Pekanbaru mengeluarkan Surat Edaran Walikota Pekanbaru Nomor : 100/Setda-Tapem/661/2020 tentang Tindaklanjut Pencegahan Penyebaran Corona Virus Disease 2019 (Covid-19) di Lingkungan Pemerintah Kota Pekanbaru. Surat edaran ini meminta masyarakat menjaga jarak (Physical Distancing) dan anjuran diam di rumah (Stay at Home). Penelitian ini bertujuan menggambarkan faktor- faktor yang mempengaruhi kemampuan Walikota memaksakan berlakunya surat edaran melalui penegakan hukum pemerintahan kepada para pihak guna memutus penyebaran Covid-19. Penelitian menggunakan pendekatan kualitatif dengan teknik pengambilan data dokumentasi. Temuan penelitian menunjukkan salah satu penyebab surat edaran ini sulit dipaksakan berlakunya disebabkan edaran walikota ini tidak memuat sanksi bagi pelanggarnya, rendahnya tingkat kesadaran hukum masyarakat dan politik pemerintah pusat.
\end{abstract}

Kata Kunci : Kekuasaan, Walikota, Beleidsregel

\begin{abstract}
The Covid-19 virus outbreak in early March 2020 spread to Indonesia, including in Pekanbaru. On March 18, 2020, 1 positive patient infected with Covid 19, was detected in Pekanbaru. Then the number of people suspected of being infected increased, so that on 22 March 2020 the Mayor of Pekanbaru, Firdaus responded in the context of government by raising the status of Covid-19 emergency response to Pekanbaru City. Furthermore, on March 23, 2020 the Mayor of Pekanbaru issued a Circular of the Mayor of Pekanbaru Number: 100 / Setda-Tapem / 661/2020 concerning the Follow-Up Prevention of Corona Virus Disease 2019 (Covid-19) in the Pekanbaru City Government. This circular asks people to keep their distance (Physical Distancing) and the suggestion of silence at home (Stay at Home). This study aims to describe the factors that influence the ability of the Mayor to impose a circular through enforcement of government law to the parties in order to decide on the spread of Covid-19. The study used a qualitative approach with documentation data collection techniques. Research findings indicate that one of the reasons for this circular is difficult to enforce due to the mayor's circular does not contain sanctions for violators, the low level of public legal and political awareness of the central government.
\end{abstract}

Keywords: Power, Mayor, Beleids 


\section{PENDAHULUAN}

Wabah Corona Virus Desease 2019 (Covid-19) telah menyebar ke berbagai daerah di Indonesia termasuk di Pekanbaru. Menurut Kepala Dinas Kesehatan Provinsi Riau, Mimi Yuliani Nazir, pada tanggal 18 Maret 2020 sudah terdeteksi 1 orang pasien positif Covid-19 di Riau. Pasien tersebut berdomisili di Pekanbaru dan sudah di rawat di Rumah Sakit Umum Daerah Provinsi Riau Arifin Ahmad, Pekanbaru tanggal 13 maret 2020 (vivanews.com, 2020). Setelah kasus tersebut, beberapa hari kemudian terjadi peningkatan signifikan jumlah masyarakat yang diduga terinfeksi Covid-19 di Pekanbaru. Diantaranya tanggal 20 Maret 2020 terdata 46 Orang Dalam Pengawasan (ODP) dan 14 orang Pasien Dalam Pengawasan (PDP), termasuk 1 pasien yang positif Covid-19. Selanjutnya hari berikutnya tanggal 21 Maret 2020 terjadi peningkatan jumlah ODP sebanyak 84,8 persen dari 46 menjadi 85 orang, sedangkan jumlah PDP meningkat dari 14 menjadi 16 orang. Berdasarkan kondisi yang dinilai darurat tersebut maka pada tanggal 22 Maret 2020, Walikota Pekanbaru, Firdaus menetapkan status Kota Pekanbaru menjadi Tanggap Darurat Covid-19 (goriau.com, 2020) .

Sebagai upaya memutus penyebaran Virus Covid-19, Walikota Pekanbaru, Firdaus membuat diskresi. Menurut Ridwan, diskresi adalah pertimbangan sendiri, wewenang untuk melaksanakan kebijakan sendiri, pertimbangan seorang pejabat publik untuk melaksanakan tugasnya, dan kekuasaan seseorang untuk mengambil pilihan melakukan atau tidak melakukkan (Muhammad Tahabrani Mutalib, 2017). Diskresi yang dalam bahasa Jerman dinamakan freies ermessen menurut Basah adalah sikap tindak yang terkait dengan : 1) ditujukan menjalankan servis publik; 2) merupakan sikap tindak yang aktif dari administrasi negara; 3) sikap tindak tersebut dimungkinkan oleh hukum; 4) sikap tindak tersebut diambil atas inisiatif sendiri; 5) sikap tindak tersebut dimaksudkan menyelesaikan persoalan persoalan penting yang timbul secara tiba-tiba; 6) sikap tindak tersebut dapat dipertanggungjawabkan kepada tuhan yang maha esa maupun secara hukum (Juliani, 2018). Dalam hasil penelitiannya yang berjudul Diskresi Dalam Penentuan Hasil Pemeriksaan Pajak Untuk Ditindaklanjuti Penegakan Hukum Pidana Dibidang Perpajakan, Sultony menyimpulkan diskresi dapat berupa pemberian alternatif kebijakan yang boleh diambil pejabat sesuai peraturan perundangan, akan tetapi diskresi sebagai wewenang yang bebas tidak dapat diartikan sebebasbebasnya. Diperlukan batasan batasan dan prosedur penggunaan diskresi agar penggunaan diskresi dapat dipertanggungjawabkan (Sultony, 2018).

Bentuk diskresi yang dibuat Walikota Pekanbaru berupa peraturan kebijakan (beleidsregels). Beleidsregel adalah salah satu instrumen pemerintahan dikenal juga sebagai peraturan kebijakan yang biasanya merupakan hasil diskresi pejabat Pemerintah. Van der Hoeven berpandangan bahwa "beleidsregel" merupakan peraturan hukum semu yang tidak memiliki kekuatan hukum yang absah, akan tetapi dalam praktik penyelenggaraan pemerintahan hal itu diberlakukan dan dipatuhi sebagaimana layaknya peraturan hukum yang sah (llmar, 2014).

Tujuan utama pembentukan beleidsregel ialah untuk memberikan arahan ( petunjuk, pedoman) kepada pejabat bawahan agar lancar dalam melaksanakan fungsi dan tugasnya.

Selain itu juga ditujukan mengisi kekosongan aturan-aturan hukum dalam keadaan yang mendesak dan bersifat darurat, atau setidaknya untuk melengkapi menyempurnakan ketentuan yang tidak sesuai lagi dengan tuntutan kebutuhan akan penyelenggaraan pemerintahan yang baik dan sesuai pula dengan sisi 
kepentingan dan kebutuhan masyarakat (llmar, 2014). Dalam praktik penyelenggaraan pemerintahan dikenal berbagai bentuk beleidsregel seperti Petunjuk Pelaksanaa (juklak), petunjuk teknis (juknis), surat edaran, pengumuman dan radiogram (Ilmar, 2014).

Beleidsregel yang dikeluarkan oleh Walikota Pekanbaru adalah Surat Edaran Walikota Pekanbaru Nomor : 100/Setda-Tapem/661/2020 tanggal 23 Maret 2020 tentang Tindaklanjut Pencegahan Penyebaran Corona Virus Disease 2019 (Covid-19) di Lingkungan Pemerintah Kota Pekanbaru. Isi surat edaran ini diantaranya meminta masyarakat menjaga jarak (Physical Distancing) dan anjuran diam di rumah (Stay at Home), termasuk menghindari kerumunan, mengumpulkan banyak orang di tempat umum termasuk di tempat ibadah dan tempat hiburan.

Surat edaran walikota tersebut sebagai sebuah beleidsregrel pada umumnya memiliki kekurangan yakni jenis sanksi yang boleh diterapkan bagi pelanggarnya. Menurut Ridwan, beleidsregel tidak boleh memuat sanksi pidana, pelanggar beleidsregel hanya dapat diberlakukan sanksi administratif (Muhammad Tahabrani Mutalib, 2017). Demikian juga Surat Edaran Walikota Pekanbaru memiliki kelemahan terkait sanksi yang diberikan bagi pelanggar surat edaran tersebut.

Meskipun beleidsregel tersebut memiliki kelemahan, Walikota Pekanbaru tetap ingin menggunakan kekuasaan yang dimilikinya untuk memaksa masyarakat patuh pada surat edaran tersebut. Kekuasaan sebagaimana diartikan oleh para ahli sebagai kemampuan pihak tertentu membuat pihak lainnya melakukan apa yang diinginkan oleh pihak tertentu tersebut. Diantaranya Weber merumuskan bahwa kekuasaan adalah kemampuan untuk dalam suatu hubungan sosial, melaksanakan kemauan sendiri sekalipun mengalami perlawanan (Budiardjo, 2015). Goodwin menjelaskan kekuasaan adalah kemampuan untuk mengakibatkan seseorang bertindak dengan cara yang oleh yang bersangkutan tidak akan dipilih seandainya tidak dilibatkan. Dengan kata lain memaksa seseorang melakukan sesuatu yang bertentangan dengan kehendaknya (Budiardjo, 2015). Menurut Etzioni dalam Poloma berpendapat bahwa kekuasaan adalah kemampuan untuk mengatasi sebagian atau semua perlawanan, untuk mengadakan perubahan-perubahan pada pihak yang memberikan oposisi (Santoso, 2001). Budiardjo (2015) berpendapat bahwa esensi dari kekuasaan adalah hak mengadakan sanksi. Cara untuk menyelenggarakan kekuasaan berbeda beda. Upaya yang paling ampuh adalah kekerasan fisik (force). Selain itu juga diselenggarakan lewat koersi, yaitu ancaman akan mengadakan sanksi. Dapat juga diselenggarakan melalui persuasi yaitu proses menyakinkan, beragumentasi atau menunjuk pendapat seorang ahli. Selain itu juga dapat diselenggarakan melalui pemberian ganjaran atau insentif, imbalan atau kompensasi.

Menurut Laswell kekuasaan yang bersifat formal disebut wewenang. Pihak yang mempunyai wewenang dianggap berhak mengeluarkan perintah dan membuat peraturan peraturan serta berhak mengharapkan kepatuhan terhadap peraturan peraturannya (Budiardjo, 2015). Demi menegakkan kepatuhan, cara-cara kekerasan atau dominasi terkadang dilegalkan, atau bisa saja cara kekerasan dan dominasi dihilangkan digantikan oleh adanya keyakinan bagi anggota anggota masyarakat bahwa wewenang yang ada pada seseorang wajar dan patut dihormati (Agus Yusoff, 2007).

Guna memaksa masyarakat patuh pada surat edaran, Walikota Pekanbaru memerintahkan Kepala Satuan Polisi Pamong Praja (Satpol PP) Kota Pekanbaru serta unsur terkait lain untuk menertibkan secara tegas rumahrumah ibadah yang masih melakukan kegiatan mengumpulkan orang banyak 
sesuai dengan ketentuan hukum yang berlaku (suarariau.co, 2020). Namun demikan surat edaran tersebut sepertinya kurang diindahkan sebagian masyarakat. Oleh karena itu, Walikota Pekanbaru, Firdaus mulai semakin tegas karena menurutnya masih ada masyarakat berkerumun di cafe dan masih banyak juga masyarakat yang datang ke tempat keramaian. Oleh karena itu, Firdaus menegaskan perintah kepada Satpol PP bertindak tegas menyelamatkan jiwa masyarakat dengan cara melarang masyarakat berkumpul di tempat keramaian atau tempat umum (riaubarometer.com, 2020).

Berdasarkan uraian tersebut dirumuskan masalah penelitian ini yaitu kekuasaan atau kemampuan Walikota Pekanbaru memaksa masyarakat untuk patuh pada isi surat edaran melalui penegakan hukum pemerintahan masih belum berhasil maksimal, yang dibuktikan masih banyaknya masyarakat yang tidak patuh. Penegakan hukum pemerintahan menurut Soekanto di pengaruhi lima faktor, yaitu :hukum itu sendiri, penegak hukum, Sarana atau fasilitas penegakan hukum, Kondisi Lingkungan masyarakat dan Kebudayaan masyarakat (IImar, 2014). Sutiyoso membedakan faktor yang mempengaruhi penegakan hukum dalam dua hal yaitu faktor yang terdapat dalam sistem dan faktor yang di luar sistem hukum. Adapun faktor dalam sistem hukum meliputi faktor hukumnya, faktor penegak hukum, faktor sarana dan prasarana. Sedangkan faktor di luar sistem hukum yang memberikan pengaruh adalah faktor kesadaran hukum masyarakat, perkembangan masyarakat, kebudayaan dan faktor politik atau penguasa negara (Bukido, 2006).

Sehubungan dengan hal
tersebut penulis mengajukan pertanyaan penelitian berupa " apa sajakah faktor yang mempengaruhi tidak maksimalnya kekuasaan Walikota Pekanbaru dalam memaksakan penegakan hukum pemerintahan berdasarkan beleidsregels kepada para pihak guna memutus penyebaran Covid- 19 di Kota Pekanbaru?".

\section{METODE}

Metode penelitian yang digunakan adalah metode kualitatif. model penelitian kualitatif adalah studi kasus dalam hal ini melihat kasus penegakan hukum pemerintahan oleh walikota pekanbaru lewat kekuasaannya.

Lokasi penelitian adalah kota Pekanbaru. Teknik pengumpulan data dilakukan melalui studi dokumentasi dengan mengambil data dari dokumen resmi milik Pemerintah Kota Pekanbaru seperti surat edaran yang dikeluarkan walikota serta informasi terkait dari website resmi Pemerintah Kota Pekanbaru, yaitu www.pekanbaru.go.id. Dokumen resmi dari berbagai media massa go.riau com, riaupos.co, suarariau.com, halloriau.com, suarariau.com, Medialaskar.com, Kumparan.com, riau24.com, vivanews.com, riaubarometer.com, cnnindonesia.com dan lain lain.

Selain itu memanfaatkan buku buku literatur terkait hukum tata pemerintahan dan politik pemerintahan. Data data dokumen yang terkumpul dianalisa sesuai tahapan analisis data yang dikemukakan oleh Miles dan Huberman yang meliputi tahap reduksi data, penyajian data yang dilanjutkan dengan penarikan kesimpulan (Emzir, 2010).

Panduan analisa data yang digunakan adalah faktor-faktor yang menurut para ahli mempengaruhi penegakan hukum. Setiap faktor yang dikemukakan para ahli di analisa menggunakan dokumen-dokumen yang tersedia, sehingga setiap faktor tergambar dengan jelas bagaimana pengaruhnya terhadap penegakan hukum pemerintahan sebagaimana yang diarahkan walikota Pekanbaru.

\section{HASIL DAN PEMBAHASAN}

$\begin{array}{ccc}\text { Beberapa } & \text { faktor } & \text { yang } \\ \text { mempengaruhi } & \text { penegakan hukum }\end{array}$


pemerintahan guna memaksa masyarakat mematuhi edaran Walikota Pekanbaru diuraikan sebagai berikut:

\section{Faktor Hukum}

Guna memutus rantai penyebaran wabah Covid-19 di Kota Pekanbaru, Walikota mengeluarkan beleidsregel berbentuk surat edaran Nomor : 100/SETDA-TAPEM/661/2020 : Tindak Lanjut Pencegahan Penyebaran Corona Virus Deseaes 2019 di lingkungan Kota Pekanbaru. Adapun isi dalam surat edaran tersebut antara lain:

a) Menetapkan status tanggap darurat selama 30 hari terhitung 21 maret sampai dengan 19 April

b) Kegiatan belajar dan mengajar siswa PAUD sampai Perguruan Tinggi dilaksanakan secara daring/ online

c) Kegiatan yang melibatkan orang dalam jumlah banyak seperti rapat kerja, rapat koordinasi, seminar/simposium/FGD, kursus dan lain-lain agar ditunda;

d) Kegiatan keramaian pada tempat hiburan ( warnet, gelanggang permainan, bilyard, bioskop, diskotik/PUB, KTV dan sejenisnya) dan kegiatan lainnya yang melibatkan massa ( unjuk rasa, pertemuan sosial, politik, budaya, agama dalam bentuk seminar, lokakarya, serasehan, konser musik, pekan raya, festival, bazaar, pameran, pasar malam, resepsi keluarga, kegiatan olah raga, kesenian, pawai dan karnaval) agar ditiadakan atau ditunda.

e) Rumah makan/ restoran/ cafe boleh beroperasi dengan mengutamakan pelayanan bawa pulang (take away) dan untuk pelayanan di tempat agar mengatur jarak duduk dengan jumlah terbatas.

f) Pelayanan publik yang diselenggarakan oleh pemerintah kota pekanbaru maupun pihak swasta tetap beroperasi dengan mengutamakan pendaftaran melalui media daring/ online dan mematuhi standar protocol covid 19.
Dalam surat edaran tersebut sebagaimana beleidsregel pada umumnya terlihat isi produk hukum ini lebih bersifat himbauan dan anjuran tidak memuat sanksi bagi pelanggarnya. $\mathrm{Hal}$ ini memang menjadi kelemahan dari surat edaran tersebut yang tidak memuat ketentuan sanksi sehingga aparat penegak hukum pemerintahan Satpol PP Kota Pekanbaru kesulitan menegakkan hukum untuk memaksakan kepatuhan pihak yang dikenai surat edaran tersebut.

Di sisi yang lain tidaknya adanya sanksi ini membuat pihak yang dikenai edaran cenderung enggan mematuhi edaran tersebut.

\section{Penegak hukum}

Penegak hukum yang menjadi garda terdepan memaksakan berlakunya surat edaran guna memutus rantai penyebaran Covid-19 yang digunakan oleh walikota Pekanbaru adalah satuan Polisi Pamong Praja Kota Pekanbaru ( Satpol PP Kota Pekanbaru).

Satuan Polisi Pamong Praja menurut Peraturan Pemerintah Nomor 16 Tahun 2018 Tentang Satuan Polisi Pamong Praja pasal 5 menjelaskan bahwa polisi Pamong Praja mempunyai tugas: 1) Menegakan Perda dan Perkada; 2) Menyelenggarakan ketertiban Umum dan Ketentraman; 3) Menyelenggarakan Perlindungan Masyarakat. Polisi Pamong Praja dijadikan ujung tombak oleh walikota guna memaksakan berlakunya surat edaran dalam rangka memberikan perlindungan masyarakat.

Walaupun edaran yang dikeluarkan tidak memuat sanksi namun Satpol PP Kota Pekanbaru berkomitmen untuk menjalankan edaran tersebut, yang ditandai :

a. Membuat Surat Himbauan Menindaklanjuti arahan Walikota Pekanbaru, kepala Satuan Polisi Pamong Kota Pekanbaru, Agus Pramono membuat surat himbauan nomor 301/Pol.PP/2020/309 kepada pemilik usaha tempat hiburan 
malam, bioskop, warnet, dan cafe serta tempat sejenisnya (tempat berkumpulnya orang) untuk sementara tidak beroperasi atau menutup segala aktivitas operasional sampai ada pemberitahuan selanjutnya dari Pemerintah Kota Pekanbaru. Satpol PP Kota pekanbaru juga menyampaikan bahwa tempat hiburan warnet, bioskop, cafe yang tidak mematuhi surat edaran akan dilakukan penyegelan atas tempat usaha tersebut. Disampaikan juga bahwa satpol PP akan senantiasa melakukan pengawasan dalam rangka memastikan surat edaran tersebut dipatuhi (halloriau, 2020)

b. Menggelar Patroli menghimbau warga stay at home

$$
\text { Satpol PP Kota }
$$

Pekanbaru juga menghimbau warga untuk tetap dirumah dan menghindari kerumunan. Satpol PP Kota Pekanbaru beserta aparat kepolisian dan unsur lainnya berkeliling setiap malam sepanjang jalan-jalan di Kota Pekanbaru pada malam hari sampai dini hari ke tempat hiburan malam, cafe dan tempat sejenis yang masih ramai pengunjung, diantaranya tanggal 26 maret 2020 melakukan patroli di Jalan Soedirman, Jalan Arifin Achmad, Jalan Soebrantas, Jalan Soekarno Hatta, dan Jalan SM Amin untuk mengingatkan masyarakat agar tidak berkerumun dan kembali pulang ke rumah (Pekanbaru.go.id, 2020).

Patroli terus dilakukan setelah pemberitahuan surat edaran di edarkan, satpol PP masih memberi himbauan sosialisasi kepada pemilik tempat usaha agar menutup sementara operasional usahanya di malam hari (pekanbaru.go.id, 2020). Kemudian tanggal 7 April 2020, Satpol PP Kota Pekanbaru juga menghimbau masyarakat menghindari kerumunan di siang hari. Diantaranya membubarkan pasar kaget di jalan utama, kelurahan Rejo Sari. Pasar kaget adalah pasar tidak resmi tempat jual beli kebutuhan sehari-hari yang biasanya cukup ramai dikunjungi pembeli.

$$
\text { Kota } \begin{gathered}
\text { Selanjutnya Satpol PP } \\
\text { Pekanbaru juga }
\end{gathered}
$$

menertibkan pedagang kaki lima yang biasanya ada berdagang di beberapa di titik di jalan protokol di kota Pekanbaru (pekanbaru.go.id, 2020)

c. Menertibkan tempat hiburan, warnet dan usaha sejenis. Satpol PP Kota Pekanbaru juga membubarkan kerumunan tempat usaha yang termasuk dalam surat edaran yang tidak mematuhi edaran walikota. Diantaranya membubarkan pengunjung 2 buah warnet tanggal 24 maret 2020 di jalan Hang Tuah di dekat simpang BPG, pengunjung warnet sebagian besar statusnya siswa sekolah. Siswa ini menyalahgunakan kesempatan libur sekolah untuk tetap dirumah, mereka malah pergi berkerumun di warnet dan tempat (riaubarometer.com, 2020) . sejenis

$$
\text { Setelah beberapa hari }
$$
himbauan di jalankan, bagi tempat usaha yang masih bandel dilakukan penyegelan. Pada Tanggal 26 Maret 2020, sebanyak 11 warnet ditutup paksa Satpol PP Kota Pekanbaru. Tanggal 27 maret 2020 siang di segel dua warnet, satu di jalan Kaharuddin nasution dan satu lagi di jalan rambutan. Tanggal 28 maret 2020, ada dua buah warget yang di segel yaitu yaitu GMC 1 
Oleh karena itu pemerintah kota Pekanbaru mengajukan izin pemberlakukan karantina Wilayah atau penerapan Pembatasan Sosial Berskala Besar (PSBB) kepada Menteri Kesehatan Republik Indonesia pada 9 April 2020.

Menurut Walikota Pekanbaru Firdaus, Kota Pekanbaru telah menerapkan lima puluh persen poin poin dalam PSBB itu, namun demikian dirasakan edaran yang dibuat belum cukup, sehingga perlu diajukan PSBB agar pemerintah kota lebih leluasa membuat kebijakan memutus rantai penyebaran Covid-19 (kumparan.com, 2020).

Beberapa hari kemudian, tepatnya tanggal 12 April 2020 permohonan PSBB Pekanbaru disetujui Menteri Kesehatan, dengan demikian pemerintah kota Pekanbaru berhak membuat kebijakan kebijakan yang lebih tepat sesuai dengan ketentuan penerapan PSBB sudah dituangkan dalam Peraturan Menteri Kesehatan (Permenkes) RI Nomor 9 Tahun 2020 tentang Pedoman Pembatasan Sosial Berskala Besar Dalam Rangka Percepatan Penanganan Corona Virus Disease 2019 (halloriau.com, 2020).

\section{KESIMPULAN DAN SARAN Kesimpulan}

Berdasarkan hasil penelitian disimpulkan bahwa faktor yang menyebabkan kekuasaan atau kemampuan walikota Pekanbaru belum maksimal dalam memaksakan berlakunya surat edaran sehingga dipatuhi masyarakat adalah :

1. Faktor hukum berupa kelemahan dalam surat edaran itu sendiri yang didalamnya tidak memuat sanksi bagi pelanggarnya. Tidak adanya sanksi yang tegas dalam edaran ini membuat sebagian masyarakat tidak patuh;

2. Rendahnya tingkat kesadaran hukum masyarakat. Walaupun edaran tersebut ditujukan untuk keselamatan masyarakat, namun disebabkan kesadaran hukum yang masih rendah, sehingga masih ada sebagian masyarakat yang tetap berkerumun mendatangi tempat keramaian tidak menjaga protokol physical distanscing dan stay at home.

3. Politik pemerintah pusat yang dari awal munculnya wabah Covid-19 di Indonesia, tidak secara cepat membuat Peraturan Perundangan untuk Memutus Penyebaran Covid19 , sehingga menyulitkan Walikota Pekanbaru bertindak lebih tegas memaksa para pihak untuk patuh pada kebijakan Walikota.

Namun demikian Walikota Pekanbaru berhasil memaksakan berlakunya edaran ini sehingga dipatuhi para pihak secara terbatas, di sebabkan oleh faktor berikut :

1. Walikota memiliki Satpol PP sebagai penegak hukum memiliki berkomitmen tinggi memberlakukan surat edaran dengan melakukan patroli membubarkan kerumunan, dan menyegel tempat usaha yang dianggap tidak patuh pada edaran Walikota;

2. Satpol PP Kota Pekanbaru memiliki fasilitas, sarana dan prasarana yang memadai untuk sehingga edaran walikota tetap bisa dipaksakan dan dipatuhi sebagian masyarakat.

\section{Saran}

Saran yang disajikan berdasarkan hasil penelitian adalah :

1. Sebaiknya setiap surat edaran memuat sanksi administratif bagi pelanggarnya. Adanya sanksi ini memudahkan penegakan hukum pemerintahan terhadap pelanggarnya.

2. Pemerintah kota perlu terus melakukan sosialisasi dengan berbagai metode guna meningkatkan kesadaran hukum masyarakat.

3. Pemerintah kota perlu melibatkan DPRD guna membuat aturan yang lebih kuat kedudukan hukumnya dibandingkan surat edaran, yaitu 
membuat peraturan daerah tentang pencegahan wabah.

\section{DAFTAR PUSTAKA}

\section{Buku}

Agus Yusoff, A. Y. (2007). Ilmu Politik: Paradigma, Makna dan Konsep

Sistem. Pekanbaru: Suska Press \& Red-PoSt Press.

Budiardjo, M. (2015). Dasar Dasar IImu Politik. Jakarta: PT. Gramedia Pustaka Utama.

Emzir. (2010). Metodologi Penelitian Kualitatif. Jakarta: PT. RajaGrafindo Persada.

Ilmar, A. (2014). Hukum Tata

Pemerintahan. Jakarta: Kencana Prenada Group.

\section{Jurnal}

Bukido, R. (2006). Paradigm and Reality of Law Enforcement. Junal IImiah Al Syir'ah, 4, 11. http://journal.iainmanado.ac.id/index.php/JIS/arti cle/view/214

Juliani, H. (2018). Jurnal

PERTANGGUNGJAWABAN

PEJABAT PEMERINTAHAN

DALAM PENGGUNAAN

DISKRESI YANG

BERPOTENSI MEMBEBANI

KEUANGAN NEGARA. (1). 1, 280-298.

Muhammad Tahabrani Mutalib.

(2017). KEWENANGAN

PENGADILAN MENGUJI

NORMA PERATURAN

KEBIJAKAN (BELEIDSREGEL)

DI INDONESIA.

https://dspace.uii.ac.id/bitstream

/handle/123456789/14960/KEW

ENANGAN PENGADILAN

MENGUJI ATURAN

KEBIJAKAN kirim ke

UII.pdf?sequence=1\&isAllowed

$=\mathrm{y}$

Santoso, T. (2001). Kekuasaan Dan

Kekerasan. Kekuasaan Dan

Kekerasan, 14(4), 89-102.
Sultony, A. (2018). Diskresi dalam penentuan hasil pemeriksaan pajak untuk ditindaklanjuti penegakan hukum pidana di bidang perpajakan. 2009, 477496.

\section{Internet}

cnnindonesia.com. (2020, maret 24).

Maklumat Kapolri Bubarkan

Massa Vs Budaya Nongkrong

Warga. Retrieved april 10, 2020, from

https://www.cnnindonesia.com/:

https://www.cnnindonesia.com/n

asional/20200323133842-12-

486042/maklumat-kapolri-

bubarkan-massa-vs-budayanongkrong-warga

goriau.com. (2020, maret 18).

Pekanbaru Umumkan Status

Tanggap Darurat Corona, Sudah

86 ODP dan 16 PDP. Retrieved

april 2020, 2020, from

https://www.goriau.com/:

https://www.goriau.com/berita/bac

a/pekanbaru-umumkan-status-

tanggap-darurat-corona-sudah-86odp-dan-16-pdp.html

halloriau. (2020, maret 21). Tempat

Hiburan, Warnet, Bioskop, Cafe di

Pekanbaru Diminta Tutup

Sementara, Tak Patuh Bakal

Disegel. Retrieved april 10, 2020, from https://www.halloriau.com: https://www.halloriau.com/readpekanbaru-127387-2020-03-21tempat-hiburan-warnet-bioskopcafe-di-pekanbaru-diminta-tutupsementara-tak-patuh-bakaldisegel.html

halloriau.com. (2020, maret 23). Di Tengah Ancaman Wabah Corona, Warga Pekanbaru Masih Berkeliaran di Luar Rumah. Retrieved april 17, 2020, from https://www.halloriau.com/: https://www.halloriau.com/readpekanbaru-127484-2020-03-23-ditengah-ancaman-wabah-coronawarga-pekanbaru-masihberkeliaran-di-luar-rumah.html 
halloriau.com. (2020, april 13). PSBB

Pekanbaru Disetujui Menkes,

Suratnya Beredar di Medsos.

Retrieved maret 16, 2020, from

https://www.halloriau.com/:

https://www.halloriau.com/read-

pekanbaru-128431-2020-04-13-

psbb-pekanbaru-disetujui-

menkes-suratnya-beredar.html

kumparan.com. (2020, april 11). Wali

Kota Pekanbaru Ajukan PSBB ke

Menteri Kesehatan. Retrieved

april 16, 2020, from

https://kumparan.com/:

https://kumparan.com/selasarriau/

wali-kota-pekanbaru-ajukan-izin-

pemberlakuan-psbb-ke-menteri-

kesehatan-1tCBKiMrmEq

Medialaskar.com. (2020, april 8). Cegah Virus Corona, Pemko Pekanbaru

Batasi Aktivitas Warga. Retrieved april 16, 2020, from

http://m.medialaskar.com/:

http://m.medialaskar.com/read-

5293-2020-04-08-cegah-virus-

corona-pemko-pekanbaru-batasi-

aktivitas-

warga.html\#sthash.PcxaY1xC.dpb $\mathrm{s}$

Pekanbaru.go.id. (2020, maret 30).

Cegah Covid-19, Satpol PP

Bersama Aparat Gabungan Gelar

Patroli dan Imbauan. Retrieved

maret 12, 2020, from

https://pekanbaru.go.id/:

https://pekanbaru.go.id/p/news/ce

gah-covid-19--satpol-pp-bersamaaparat-gabungan-gelar-patrolidan-imbauan-

pekanbaru.go.id. (2020, april 17). Pasar Kaget Dibubarkan Satpol PP.

Retrieved april 13, 2020, from https://pekanbaru.go.id/: https://pekanbaru.go.id/p/news/pa sar-kaget-dibubarkan-satpol-pp

pekanbaru.go.id. (2020, maret 26).

Satpol PP Gelar Patroli Gabungan Ajak Masyarakat Cegah Covid-19. Retrieved april 12, 2020, from https://pekanbaru.go.id/:

https://pekanbaru.go.id/p/news/sat pol-pp-gelar-patroli-gabunganajak-masyarakat-cegah-covid-19- riau24.com. (2020, maret 26). Bubarkan

Kerumunan Massa, DPRD

Pekanbaru Apresiasi Langkah

Tegas Kepolisian. Retrieved april

15, 2020, from

http://www.riau24.com/:

http://www.riau24.com/berita/baca

/1585185750-bubarkan-

kerumunan-massa-dprd-

pekanbaru-apresiasi-langkah-

tegas-kepolisian

riaubarometer.com. (2020, maret 24).

https://riaubarometer.com.

Retrieved april 14, 2020, from Tak

Hiraukan Imbauan Terkait

Pencegahan Corona, 2 Warnet Di

Pekanbaru Masih Buka:

https://riaubarometer.com/tak-

hiraukan-imbauan-terkait-

pencegahan-corona-2-warnet-dipekanbaru-masih-buka/

riaubarometer.com. (2020, maret 28).

Keras! Walikota Pekanbaru Minta

Warga Tetap Di Rumah: Duduk-

Duduk Di Kafe Itu Artinya Bunuh

Diri. Retrieved april 2019, 2020,

from https://riaubarometer.com/:

https://riaubarometer.com/keras-

walikota-pekanbaru-minta-warga-

tetap-di-rumah-duduk-duduk-di-

kafe-itu-artinya-bunuh-diri/

riaupos.co. (2020, maret 28 ).

riaupos.jawapos.com. Retrieved

april 12, 2020, from

https://riaupos.jawapos.com/:

https://riaupos.jawapos.com/peka nbaru/28/03/2020/228067/11warnet-ditutup-paksa-duadisegel.html

suarariau.co. (2020, maret 27). Masih

Ditemukan Kegiatan Keramaian,

Wako Minta Tim Gugus Tugas

Percepatan Penanganan Corona

Tindak Secara Hukum. Retrieved

maret 19, 2020, from

http://suarariau.co/:

http://suarariau.co/baca/berita/158

5264660masih-ditemukan-

kegiatan-keramaian-wako-minta-

tim-gugus-tugas-percepatan-

penanganan-corona-tindak-

secara-hukum 
JURNAL ILMIAH MUQODDIMAH

Jurnal IImu Sosial, Politik, dan Humaniora

vivanews.com. (2020, maret 18). Satu

Warga Riau Positif Terinfeksi

Virus Corona Covid-19. Retrieved

april 19, 2020, from

https://www.vivanews.com/:

https://www.vivanews.com/berita/n

asional/41178-satu-warga-riau-

positif-terinfeksi-virus-corona-

covid-19?medium=autonext 